\title{
A FUZZY APPROACH TO SELECTING ROOF SUPPORTS IN LONGWALL MINING
}

\author{
M.E. Yetkin ${ }^{1 *}$, F. Simsir ${ }^{1}$, M.K. Ozfirat ${ }^{1}$, P.M. Ozfirat ${ }^{2} \&$ H. Yenice $^{1}$
}

\section{ARTICLE INFO}

Article details

Submitted by authors

Accepted for publication 21 Feb 2016

Available online $\quad 10$ May 2016

Contact details

Corresponding author

mustafa.yetkin@deu.edu.tr

\section{Author affiliations}

$1 \quad$ Mining Engineering Department Dokuz Eylul University, Izmir, Turkey

2 Industrial Engineering Department

Celal Bayar University Manisa, Turkey

http://dx.doi.org/10.7166/27-1-1366

\section{ABSTRACT}

As a decision-making problem, selecting proper machines and equipment plays a key role for mining sites and companies. Many factors affect this decision, and values belonging to these factors can be expressed numerically and/or non-numerically. In order to make the most appropriate decision, engineers must carry out an evaluation process that comprises all criteria that might affect decision-making. To achieve this, multi-criteria decision-making tools are used. As a result of technological developments, coal outputs in longwall mining have risen tremendously over the last decades, and longwall mechanisation has become unavoidable. The significance of powered roof supports in particular increases dayby-day, since the rate of roof support has to be in accordance with the rate of face advance in longwalls.

In this study, an integrated fuzzy analytic hierarchy process and fuzzy goal programming model is used to select the most suitable powered roof supports. The procedure is applied to a real-life underground coal mine that is operated using the longwall method. Seven alternative powered roof supports are compared with each other, taking a total of 24 decision criteria under four main topics into account. In conclusion, the most suitable roof supports for the mine under study are determined and recommended to the decision-makers of the system.

\section{OPSOMMING}

' $n$ Die selekteer van die regte masjinerie en toerusting speel ' $n$ sleutelrol vir myn werwe en mynmaatskappye. Daar is baie faktore wat dié besluit beïnvloed en numeriese of nie-numeriese waardes kan aan hierdie faktore toegeken word. Om die regte besluit te neem, moet ingenieurs al die kriteria wat die besluit mag beïnvloed oorweeg. Hiervoor word multi-kriteria besluitnemingstrategieë gebruik. As gevolg van tegnologiese ontwikkelinge, het die steenkoolontginning van ondergrondse myne drasties toegeneem en is meganisering van dié myne onvermeidelik. Die belang van aangedrewe plafonstutte het veral toegeneem as gevolg van die vinnige tempo van skag verlenging.

'n Wasige analitiese hiërargieproses en wasige doelbeplanningsmodel word gebruik om die gepaste aangedrewe plafonstutte te kies. Die prosedure word toegepas op 'n ondergrondse steenkoolmyn. Sewe aangedrewe plafonstutte word met mekaar vergelyk; die vergelyking neem 24 besluitnemingskriteria, wat onder vier hoofafdelings verdeel is, in ag. Gevolglik word die mees geskikte plafonstut gekies en aanbeveel. 
Excavation of coal in the panel is an almost continuous operation in longwall production. High energy consumption governs the corresponding level of coal extraction. One of the underground coal extraction methods is longwall mining. This is a highly productive process for coal extraction with a high recovery rate. High-technology equipment and efficiency, mechanisability, and extraction of coal seams with high inclination and depth have made this process attractive for mining engineers [1]. The cost of powered supports dominates other production costs in the longwall mining. Therefore, proper selection of powered supports that meet the demands of the face support and are economical has always been the main concern for mining engineers [2]. The longwall face is supported by hydraulic roof supports whose main function is to provide a safe working environment as the coal is extracted and as the longwall equipment advances $[3,4]$. In some sense, longwall mechanisation is closely related to the support system applied in-face. By being able to create a prop-free area along the face, the miner is provided with a great opportunity to use in-face mechanisation. By using powered roof supports, operation of shearerloaders and workers in-face has become easier and less problematic.

In a fully-mechanised longwall, the cost of powered roof supports comprises the bigger part of investment costs. Moreover, the proper selection of support units that are appropriate for their working conditions is highly important. So determining the necessary parameters for selecting powered roof supports is gaining significance, and this has become the most important stage of the selection procedure. In order to select the most suitable roof supports, a fuzzy analytic hierarchy process (FAHP) methodology is employed in this study.

Selection problems include conflicts, owing to their very nature. In the mining industry, investments in machinery and equipment involve extremely high costs. So the wrong selection of machinery and equipment would incur very high costs for the firm, as would inefficient production or lower work safety. Most of the time, the mine's decision-makers simply select the cheapest machinery. However, there are many other important criteria for the operation of the mine; some of these can be the machinery's technical properties, the mine's geological properties, work safety characteristics, and the mine's structure. Simply selecting the cheapest machine and equipment without considering other criteria may be useless and even disastrous for the operation of the mine.

Fuzzy methods in selection problems are employed because they give decision-makers more flexibility and decrease decision errors when making comparisons. For example: machines $A$ and $B$ are compared. If the decision-maker states that machine $A$ is three times more effective than machine $B$, this remark sounds too categorical and rigid, and it is very likely that the decisionmaker is making an error. However, if the decision-maker states that machine $A$ is at least two times and at most four times more effective than machine $B$, then the decision-maker is less likely to make an error. So, in order to decrease human error in decision-making and provide more flexibility, fuzzy numbers are used in this study for selecting roof supports.

In the proposed methodology, the decision criteria that are effective for roof support and the alternative roof supports are determined first. Then these criteria are compared with each other using fuzzy triangular numbers. After finding lower bounds, mid-values, and upper bounds on the priorities of criteria by analytic hierarchy process (AHP), a fuzzy goal programming model is used to compute the final priorities. By using these weights and the performance values of alternative roof supports, a final performance value is computed for each roof support, and the most suitable supports are recommended. In addition, a real-life case is solved using the proposed procedure. This procedure was previously used for the road header selection problem in underground mining [5]. However, this is the first study in the literature that handles the problem of roof support selection using the proposed fuzzy AHP procedure.

In this study, the parameters that are effective in the selection of powered roof supports are handled under four main topics. Although these parameters can vary depending on the working conditions that support units will face, they are the main parameters to be considered. These main topics are geology (C1), the geomechanical properties of coal and surrounding rocks (C2), production (C3), and equipment (C4). Then, for each of these main criteria, sub-criteria have been determined. The main criteria and the sub-criteria are then processed using the fuzzy AHP 
method, and in this way the most appropriate support type is determined (Figure 1). A total of 24 sub-criteria are defined under the four main topics, as shown in Table 1.

Table 1: Main criteria and sub-criteria affecting powered roof support selection in longwall mining

C1: Geology
C11: Working depth
C12: Seam thickness
C13: Structures
C14: Seam inclination
C15: Water condition
C16: In situ stress
C17: Caving behaviour
C2: Geomechanical properties of coal and surrounding rocks
C21: Mechanical properties of hanging wall
C22: Mechanical properties of footwall
C23: Mechanical properties of coal

Table 1 (cont.): Main criteria and sub-criteria affecting powered roof support selection in longwall mining

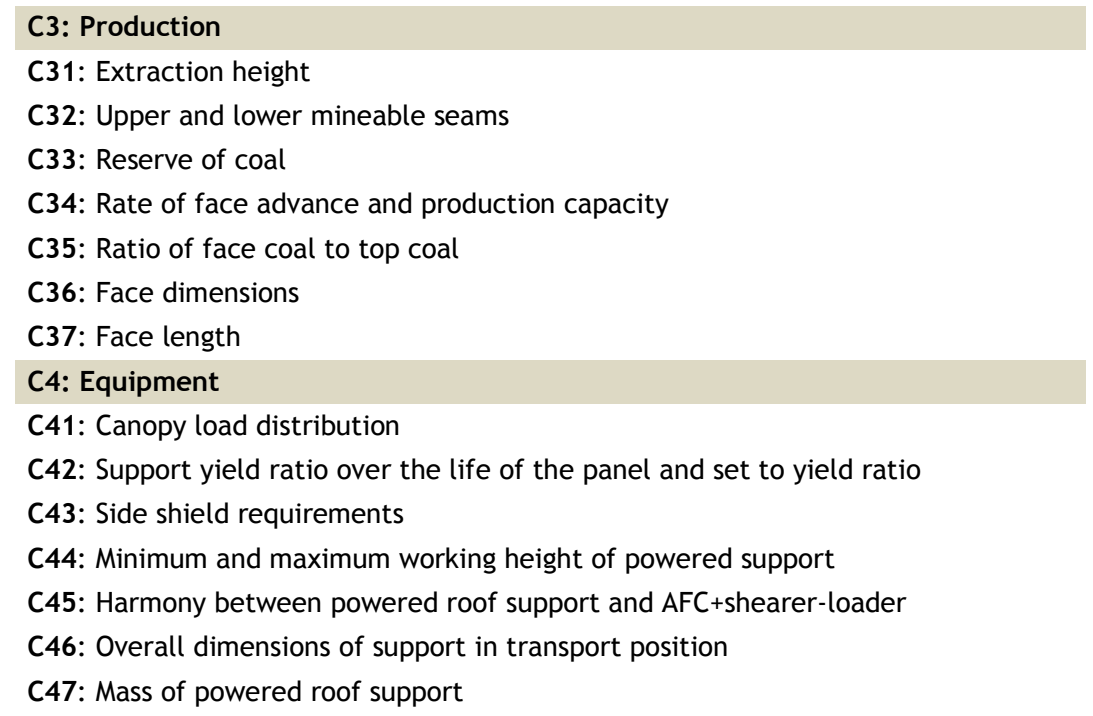

\section{CRITERIA CONSIDERED WHEN SELECTING POWERED ROOF SUPPORTS}

Mine planning begins with gathering geological information at several scales, starting with premining surface core drilling and geophysics. Seven sub-criteria were determined under the main topic of 'geology (C1)': the working depth (C11), seam thickness (C12), structures (C13), seam inclination (C14), water condition (C15), in situ stress (C16), and caving behaviour (C17). Working depth (C11) and seam thickness (C12) are important criteria in the selection process because they relate to calculating the loads that affect the support unit. As the seam thickness increases, the height of the immediate roof also increases, which means that the support unit has to carry more load [6] (Figure 2). 


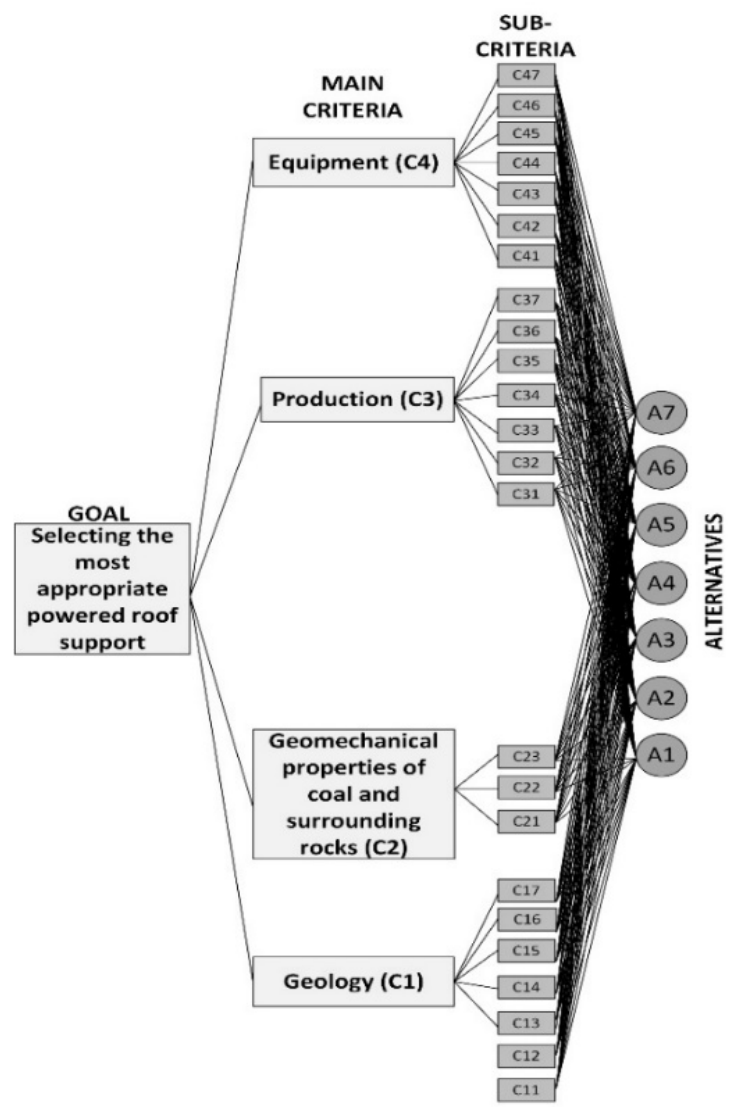

Figure 1: Hierarchy design for the powered roof support selection process

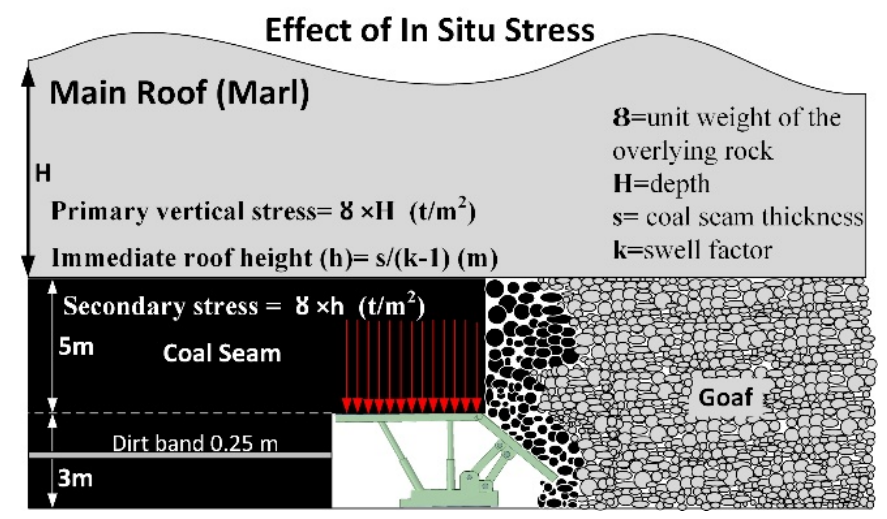

Figure 2: Effect of in situ stress

Structural features (C13) such as faults and dirt bands adversely affect underground production and the type of powered roof support that is needed. Thick dirt bands of high strength reduce coal cutting speed and overall efficiency, and so have a negative effect on mechanisation. In the case of thick dirt bands, the mining method has to be changed and suitable support units have to be selected (Figures 3 and 4). Powered roof support units can operate in seams dipping (C14) to a maximum of $35^{\circ}[7]$. 


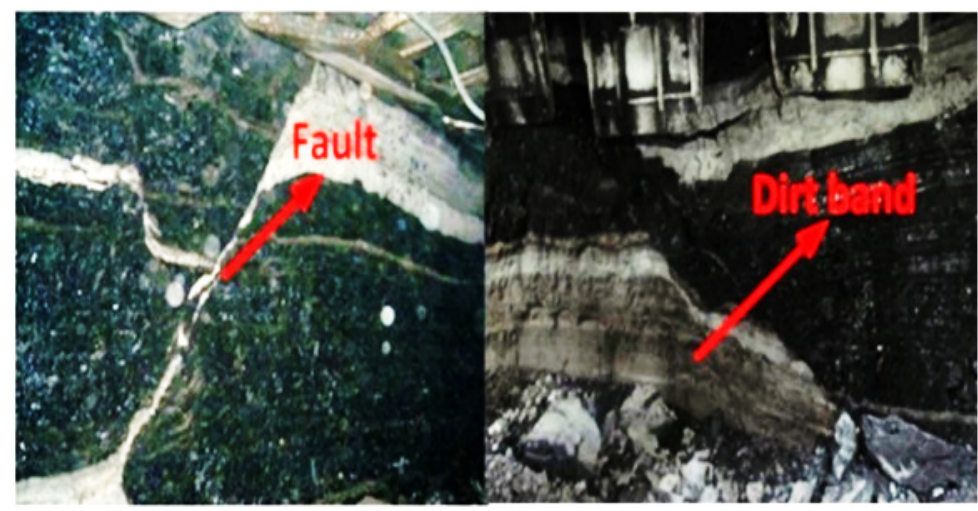

Figure 3: Fault and dirt band

In addition, water (C15) that usually comes from faulty zones generally softens the footwall and causes the roof support, which is a heavy construction, to sink into the soft footwall. This means a deterioration in the alignment of the roof support units and, as a result, face operation has to stop and coal production is interrupted. One of the important parameters affecting the selection of powered roof supports is the state of in situ stresses (C16). For the evaluation of selecting support systems with numerical modelling, the magnitude and direction of in situ stress must be defined [8] (Figure 2). The vertical stress estimated from Equation 1 has been used to generate the vertical in situ stress field.

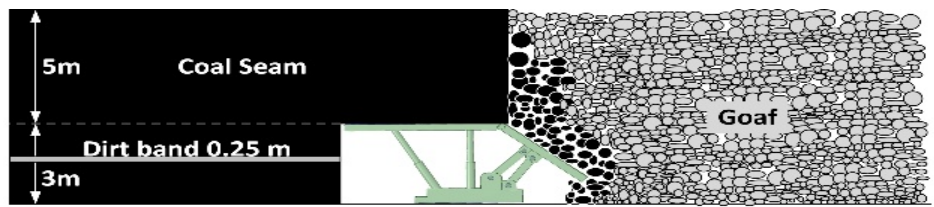

(a)

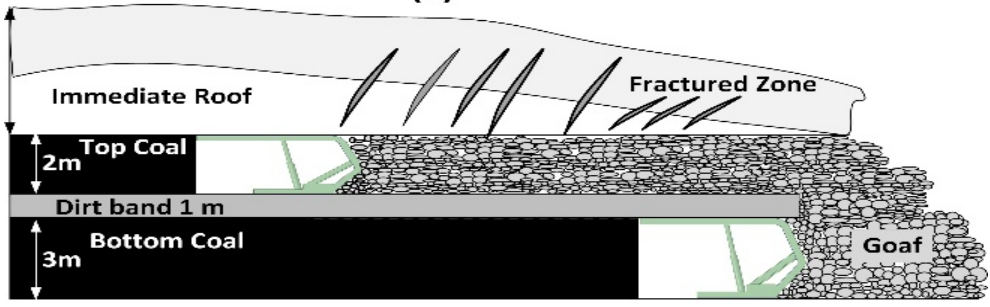

(b)

Figure 4: Effect of dirt band in selecting powered roof support

$$
\sigma_{\mathrm{v}}=\gamma \times \mathrm{h}
$$

where $\sigma_{\mathrm{v}}$ is the vertical stress $\left(\mathrm{t} / \mathrm{m}^{2}\right), \gamma$ is the unit weight of the overlying rock $\left(\mathrm{t} / \mathrm{m}^{3}\right)$, and $\mathrm{h}$ is the depth below surface $(\mathrm{m})$ [9]. The caving behaviour (C17) of the roof ceases when the gap from the floor to the roof is filled with broken and loose material. When this material is subjected to stress, two main parameters control its compaction process: the initial bulking factor, and the strength of the rock fragments $[6,10,11]$. With the increasing compaction of goaf material, the stresses in goaf increase also, and additional stresses affect the caving shield of the support unit. In this case, selection of the support unit has to be done while considering the goaf pressure calculated by numerical analysis methods.

Under the main topic of 'geomechanical properties of coal and surrounding rocks (C2)', three subcriteria were defined. The mechanical properties of the hanging wall (C21) play a very important role in support performance. The peak front abutment stress at the face increases almost linearly with the increase in strata strength [9]. The mechanical properties of the footwall (C22) should be strong, and should have a hardly cracked and undulated structure, since roof supports and excavation machines work on the footwall; otherwise, they would sink and careen to the footwall 
[12]. The mechanical properties of the hanging wall (C21), the footwall (C22), and coal (C23) are highly important because they help to predict the loads acting on the support units. Nowadays, the main input parameters for finite-element-methods used to investigate support performances are the geomechanical features of the hanging wall, footwall, and coal itself.

Under the main topic of 'production (C3)', seven sub-criteria were defined. In general, the higher the extraction height $(\mathrm{C} 31)$, the greater the potential for face spall and the larger the canopy tipto-face distances. A large extraction height range for longwall supports can offer both advantages and disadvantages. Leg size has been designed to ensure sufficient stiffness and stability at high extraction heights [13]. The presence of coal seams of mineable thickness that consist of several thicknesses in different areas is called 'upper and lower mineable seams (C32)'. In this case, a support unit has to be selected that is suitable for the coal seams' thicknesses. In the upper longwall, this is a support unit that is as high as the face; in the lower face, it is a support unit allowing some of the caved top coal to be retracted from the face rear (Figure 5). Considering the investment costs of a fully-mechanised longwall, support units constitute the biggest portion; therefore, to compensate for the costs and to make a profit, reserves of coal (C33) must be high enough where these support units are to be used. In order to meet annual coal production, the rate of face advance (C34) can be set at a high value. In this case, the support unit to be selected must be suitable for high face advance rates. The ratio of face coal to top coal height (C35) changes the ground pressure at the face and the way the top coal breaks. This makes top coal breaking and caving easier, and increases top coal recovery. So a support unit must be selected that has the highest compatibility with this breaking mechanism [14]. Since face development work and moving in-face equipment to another panel takes too long, the longest possible face length (C37) should be chosen. Face dimensions (C36), on the other hand, should be selected to ease the movement of the support unit.

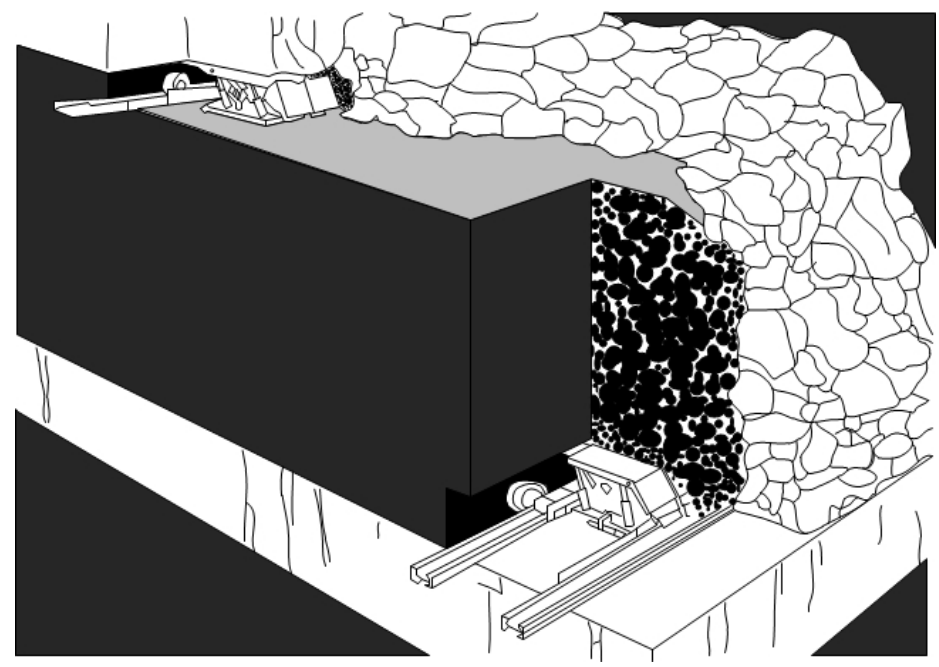

Figure 5: Upper and lower mineable seams [15]

Under the main topic of 'equipment (C4)', seven sub-criteria were defined. The distribution of loading on the canopy (C41) is also dependent upon the stiffness of these components and the deformation characteristics of the immediate strata. The canopy should be in full contact with the hanging wall, and should be designed so that it transfers the loads it receives proportionally to other support unit elements. Setting forces have increased in proportion to the increase in yield capacity. Most hydraulic power supply systems and electro-hydraulic control technologies still try to maintain a set-to-yield ratio $(\mathrm{C} 42)$ in the 0.6 to 0.8 range. Moreover, the yield ratio should be high enough to avoid deformations, which are likely to occur over panel life on the support unit's elements because of high load accumulations [16]. For side shields requirements (C43), side shields can be used to steer the face. In this case, inappropriate management and operation of this facility can create canopy-to-base misalignment [17]. Changes in support capacity, stiffness, and load distribution on the canopy and base should be determined as a function of the operating height (C44) and as part of the design and performance testing procedure [18]. The powered roof support must be able to operate in-face in accordance with the chain conveyor and the shearerloader (C45). In this way, problems likely to occur in future that might cause production loss can 
be prevented. The overall dimensions of support in the transport position (C46) are important features with regard to the moving ability of the unit into the face. So the dimensions of the support unit in moving status must be in accordance with the main haulage road and in-seam galleries. The mass of the powered roof support (C47) must be chosen by taking account of the footwall characteristics of the face. If the footwall in-face is too weak, support units can sink into the bottom formation or a deterioration in the support alignment can occur.

\section{CASE STUDY}

The state-run Omerler colliery of the Turkish Coal Enterprises is situated in the inner western part of Turkey, $13 \mathrm{~km}$ from Tavsanli and $63 \mathrm{~km}$ from Kutahya (Figure 6). The total proven lignite reserve of the basin is about 330 mega tonnes. Of this reserve, 263 mega tonnes is suitable for underground production and the rest can be mined in open pits. The average heat value of lignite in the Tuncbilek basin is $4,500 \mathrm{kcal} / \mathrm{kg}$, with an average sulphur content of 1.5 per cent. The Omerler colliery started production in 1985, and employs a retreat longwall with top-coal caving. A conventional support system was used until 1997, when a fully mechanised face was established. The average working depth is approximately 240 metres below the surface. The thickness of the coal seam dipping by $10^{\circ}$ is eight metres. Laboratory studies have been carried out on core samples taken from the JT-4 borehole, which was drilled to investigate the geomechanical features of the surrounding rock of the coal seam in the working area. The results of these studies are given in Table 2 [19-22].

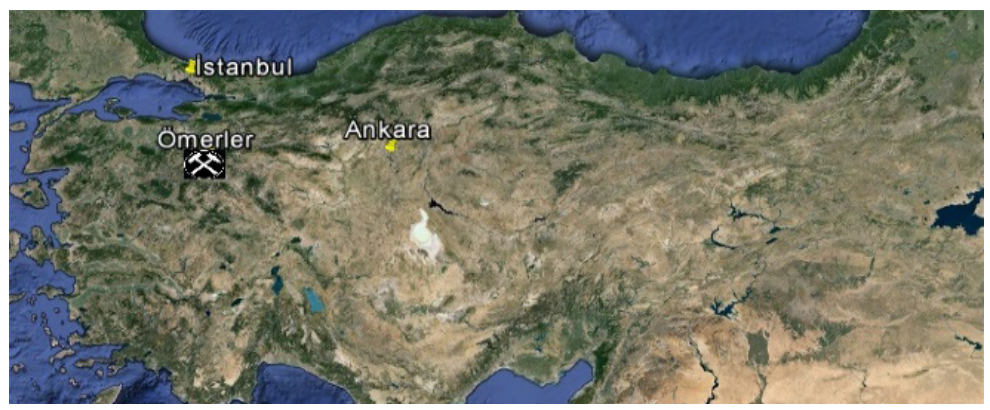

Figure 6: Location map of field site

Table 2: Geomechanical properties of coal's surrounding rocks [19-22]

\begin{tabular}{|c|c|c|c|c|c|c|c|}
\hline & & & & & & \multicolumn{2}{|c|}{} \\
Formation & $\begin{array}{c}\text { Density } \\
\left(\mathrm{gr} / \mathrm{cm}^{3}\right)\end{array}$ & $\begin{array}{c}\text { Porosity } \\
(\%)\end{array}$ & $\begin{array}{c}\text { Water } \\
\text { content } \\
(\%)\end{array}$ & UCS & TS & \multicolumn{2}{|c|}{ TCS } \\
\cline { 5 - 9 } & & & & $\mathrm{MPa}$ & $\mathrm{MPa}$ & $\begin{array}{c}\mathrm{C} \\
(\mathrm{MPa})\end{array}$ & $\begin{array}{l}\emptyset \\
\left({ }^{\circ}\right)\end{array}$ \\
\hline Clay stone & 2.093 & 25.30 & - & 10.20 & 1 & 2.50 & 50 \\
\hline $\begin{array}{c}\text { Calcareous } \\
\text { marl }\end{array}$ & 2.278 & 13.80 & - & 29.20 & 3.90 & 12.50 & 47 \\
\hline Limestone & 2.501 & 4.30 & - & 64.26 & - & - & - \\
\hline Marl & 2.181 & - & 14.2 & 16.10 & 1.90 & 5 & 31 \\
\hline
\end{tabular}

$C=$ Cohesion; $\varnothing=$ Internal friction angle; UCS = Uniaxial compressive strength; TS = Tensile strength; TCS = Triaxial compressive strength .

The position of the fully-mechanised coal panel A5 of Omerler colliery is given in Figure 7 . The panel lies 207 metres below the surface, where the coal thickness is an average of eight metres. The panel length is about 400 metres, the face length is 91 metres, and the face comprises 52 powered roof support units. The thickness of the immediate roof is approximately 17 metres, with 182 metres of main roof over it. Three metres of the coal seam is mined from face, while the other five metres is caved and retracted from the face rear (Figure 4). 

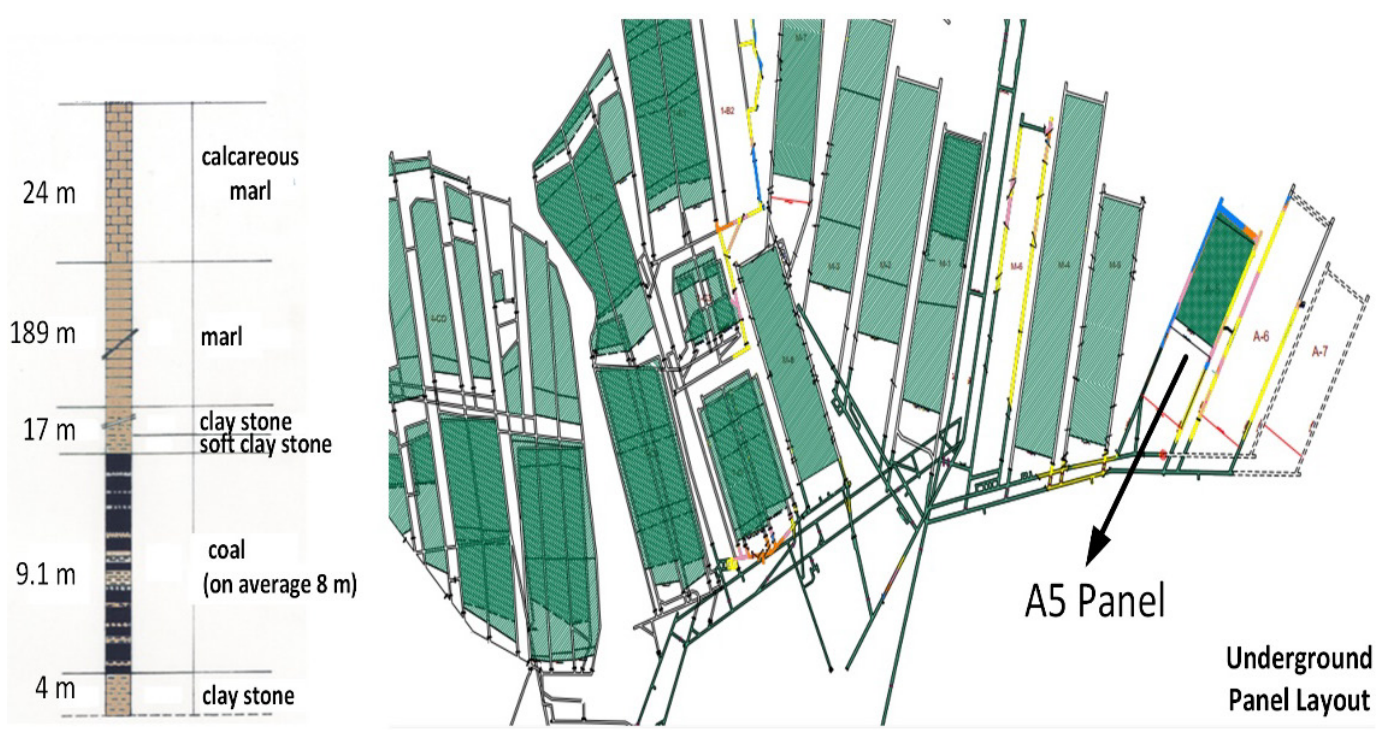

Figure 7: View of the panels and stratigraphic structure of coal seam [23]

\section{APPLICATION OF THE PROPOSED METHODOLOGY FOR SELECTING THE POWERED ROOF SUPPORT}

The problem of powered roof support selection is considered, and the proposed methodology is applied to this problem.

\subsection{Motivation for the study}

A fuzzy number is a generalisation of a real number where the number does not refer to a single value, but refers to a set of possible values. The possibility of each value is associated with a coefficient between 0 and 1 . This coefficient is called the membership function, and it shows the membership degree of the value in that set.

Three types of widely-used fuzzy numbers are the triangular, trapezoidal, and Gaussian fuzzy numbers (Figure 8). In this study, triangular fuzzy numbers are employed to represent the comparisons among decision criteria. The reason for choosing triangular fuzzy numbers is that we need to define an interval for pairwise comparisons (with a lower and upper bound). Within this interval, there should be only one value that is the most likely value for the specific comparison. This definition leads us to a triangular fuzzy number (Figure 8a). In addition, triangular fuzzy numbers are easier to understand and use for practitioners in the field of mining.
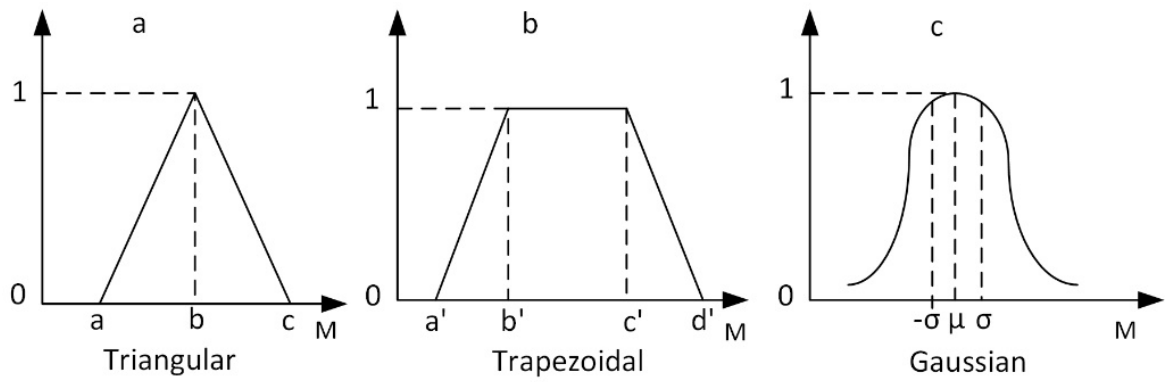

Figure 8: Three types of widely-used fuzzy numbers [24]

As seen in Figure 8, a fuzzy triangular number has a lower bound $(a)$, an upper bound (c), and a most-likely value $(b)$ between the lower and upper bounds. The membership function $\mu(x)$ is given in Equation 2. It should be noted that $\mu(x)$ takes the value of 1 if the number is equal to the most 
likely value $(b)$, and takes the value of 0 if the number is less than the lower bound $(a)$ or more than the upper bound $(c)$.

$$
\mu(x)=\left\{\begin{array}{cl}
0 & \text { if } x \leq a \text { or } x \geq c \\
\frac{x-a}{b-a} & \text { if } a \leq x \leq b \\
\frac{c-x}{c-b} & \text { if } b \leq x \leq c
\end{array}\right\}
$$

Since investment costs are very high in the mining industry, The selection of machinery and equipment should be given high priority and be carried out accurately. Wrong decisions might lead to very high costs, disastrous accidents, or very low productivity values. In this study, the FAHP approach is used to select powered roof supports in an underground coal mine.

Fuzzy approaches have had very limited application in the mining industry. However, fuzzy logic has positive effects on decreasing errors, increasing flexibility, and providing more accurate solutions. Therefore, fuzzy approaches need to be introduced and presented to the mining industry.

The FAHP approach used in this study was originally proposed for the roadheader selection problem in metal mines. In this study, it is employed for the roof support selection problem of an underground coal mine. The fuzzy mathematical model is modified according to the current problem. Since coal mines and metal mines are very different in geology and operation, Omerler coal mine requires that different and specific decision criteria and comparisons are made by experts in the system.

\subsection{Step 1: Determine powered roof support alternatives}

Seven alternative roof supports are identified for the mine under study. These are referred to as A1 to A7. Figures and the technical properties of these roof supports are given in Figure 9.
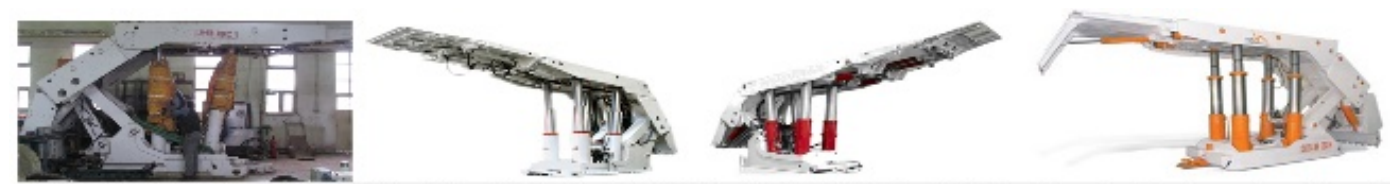

A1: Roof Support; Closed-A2: Roof Support; Closed-A3: Roof Support; Closed- A4: Roof Support; ClosedExtended Height $(\mathrm{m}), 2-3.4$, Extended Height $(\mathrm{m}), 2.9-5.2$, Extended Height (m), 2.3-3.7, Extended Height $(\mathrm{m}), 1.68-3.04$, Support Resistance $(t), 740$ Support Resistance ( $t$ ), 1530 Support Resistance (t), 1020 Support Resistance (t), 690

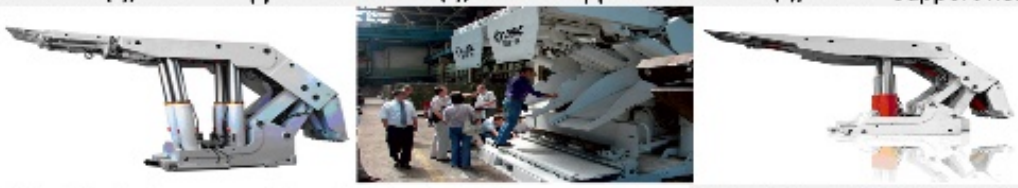

A5: Roof Support; Closed- A6: Roof Support; Cloșed-A7: Roof Support; ClosedExtended Height (m), 2.75-4.2, Extended Height (m), 2.1-3.2, Extended Height (m), 2.3-4.0, Support Resistance (t), 1530 Support Resistance (t), 420 Support Resistance (t), 1224

Figure 9: Alternative roof supports identified for the study

These roof supports are specially designed for the mining of thick coal seams. The support units $\mathrm{A} 1, \mathrm{~A} 2, \mathrm{~A} 3, \mathrm{~A} 4, \mathrm{~A} 5$ and $\mathrm{A} 7$ operate using double chain conveyors, while $\mathrm{A} 6$ is a roof support with a drawing window for caved top coal. In addition, A6 and A7 have two hydraulic cylinders, whereas the rest of the roof supports have four hydraulic cylinders. The position of the hydraulic legs varies between perpendicular and oblique relative to base. This positioning affects both the ability of workers to pass through and the bearing capacity of the support unit. The maximum working heights of the units are between 3.2 and 5.2 metres, and the bearing capacities range between 420 and 1,530 tonnes. 
These seven alternative powered roof supports are evaluated in terms of the 24 decision criteria identified under the four main headings presented earlier. All the decision criteria and the alternative roof supports are listed in Figure 10.

\subsection{Step 2: Build pairwise comparison matrices using fuzzy triangular numbers}

The fuzzy pairwise comparisons for the main selection criteria can be seen in Figure 11 . The comparisons are made using Saaty's scale of nine [25]. Fuzzy comparisons in the matrices can be read as: "The seam thickness criterion (C12) is at least as important as the structures criterion (C13), and it is at most moderately more important than the structures criterion (C13)". As seen in Figure 11, the fuzzy triangular number for comparing the seam thickness criterion (C12) and the structures criterion $(\mathrm{C} 13)$ is $(1,2,3)$. Here, according to Saaty's scale, 1 stands for equally important and 3 stands for moderately important [25]. The reader should note that at this step, decision criteria are compared with each other using fuzzy numbers. Fuzzy numbers are not compared with each other.

Similarly, sub-criteria are compared within each group using fuzzy triangular numbers. These matrices can also be seen in Figure 11. Only the right side of the diagonal is filled in, since the left side of the diagonal is found by taking the inverse of the transposed cell.

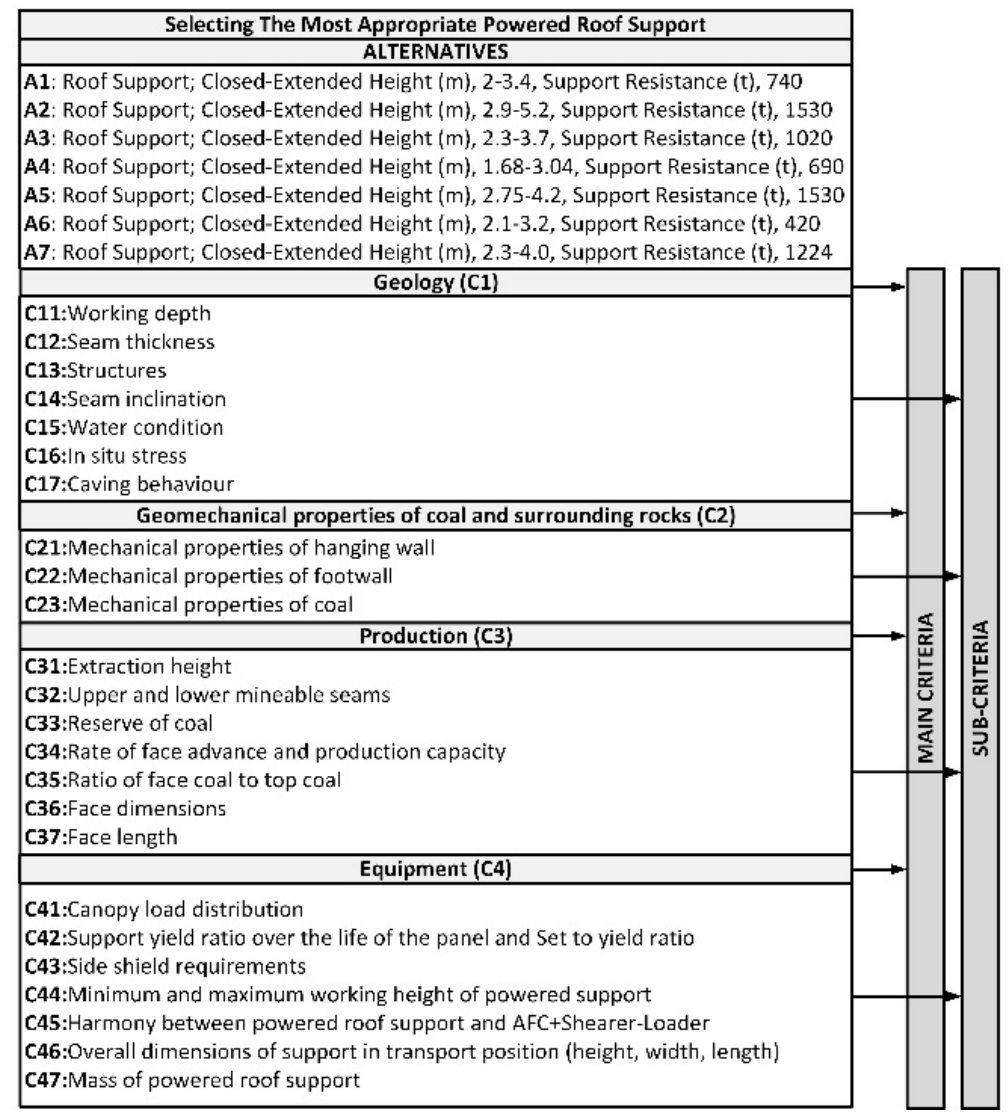

Figure 10: Main criteria and sub-criteria affecting the problem of selecting powered roof supports 


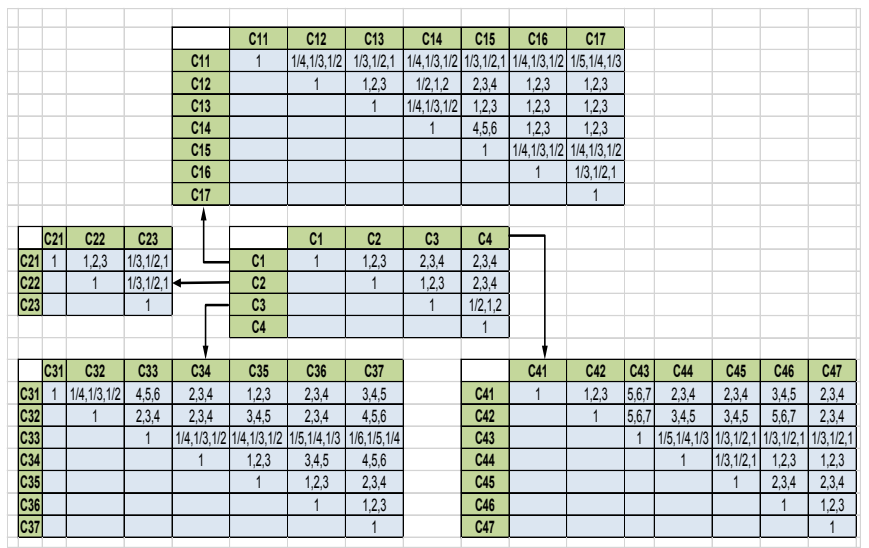

Figure 11: Pairwise comparisons using fuzzy triangular numbers

\subsection{Step 3: Find lower bounds, mid-values and upper bounds of priorities}

The comparison matrices are split into three: $A_{\text {lower }}, A_{\text {middle }}$ and $A_{\text {upper }}$ (Figure 12). Lower bounds, mid-values, and upper bounds for priorities are computed by AHP using these three matrices respectively. A similar computation is made for all sub-criteria groups [5,26-27]. The three sets of priorities for all criteria can be seen in Table 3 .

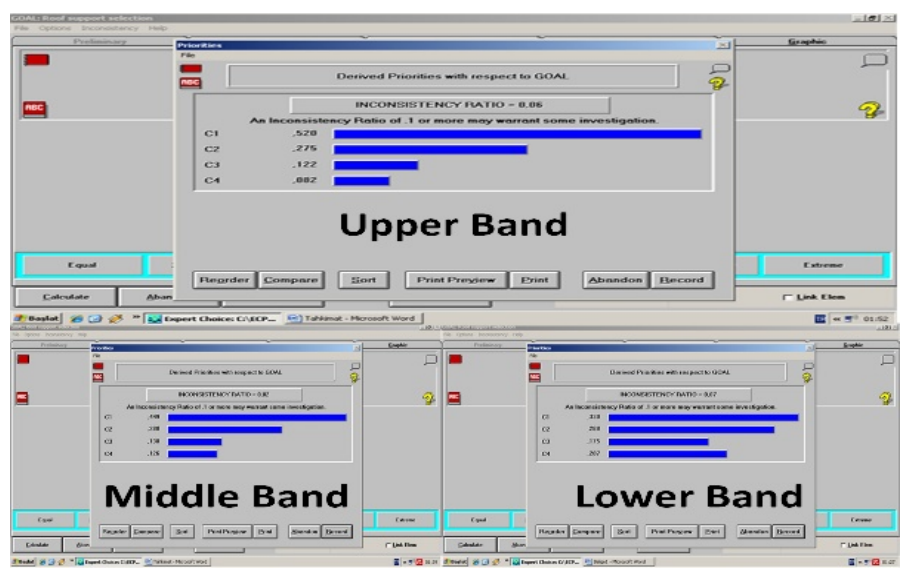

Figure 12: Evaluation of main criteria for the lower, middle, and upper values [28]

Table 3: Lower bounds, mid-values and upper bounds for each criterion

\begin{tabular}{|c|c|c|c|c|c|}
\hline Sub-criteria & Lower bound & Sub-criteria & Mid-value & Sub-criteria & Upper bound \\
\hline C14 & 0.105 & C14 & 0.142 & C12 & 0.173 \\
\hline C17 & 0.097 & C12 & 0.122 & C14 & 0.139 \\
\hline C23 & 0.092 & C23 & 0.091 & C13 & 0.094 \\
\hline C16 & 0.068 & C13 & 0.081 & C21 & 0.091 \\
\hline C42 & 0.063 & C17 & 0.081 & C23 & 0.066 \\
\hline C12 & 0.061 & C16 & 0.063 & C17 & 0.063 \\
\hline C32 & 0.055 & C21 & 0.056 & C16 & 0.057 \\
\hline C41 & 0.044 & C32 & 0.050 & C11 & 0.053 \\
\hline C13 & 0.040 & C41 & 0.044 & C22 & 0.051 \\
\hline C45 & 0.036 & C42 & 0.038 & C32 & 0.041 \\
\hline
\end{tabular}


Table 3: Lower bounds, mid-values and upper bounds for each criterion (cont.)

\begin{tabular}{|c|c|c|c|c|c|}
\hline Sub-criteria & Lower bound & Sub-criteria & Mid-value & Sub-criteria & Upper bound \\
\hline C34 & 0.032 & C22 & 0.032 & C31 & 0.036 \\
\hline C31 & 0.031 & C15 & 0.032 & C15 & 0.034 \\
\hline C15 & 0.027 & C31 & 0.029 & C41 & 0.027 \\
\hline C21 & 0.031 & C11 & 0.029 & C42 & 0.031 \\
\hline C22 & 0.020 & C34 & 0.022 & C34 & 0.031 \\
\hline C35 & 0.012 & C45 & 0.017 & C35 & 0.024 \\
\hline C44 & 0.008 & C35 & 0.014 & C36 & 0.023 \\
\hline C47 & 0.008 & C44 & 0.013 & C44 & 0.023 \\
\hline C36 & 0.008 & C36 & 0.011 & C45 & 0.020 \\
\hline C46 & 0.006 & C46 & 0.009 & C37 & 0.019 \\
\hline C37 & 0.005 & C37 & 0.008 & C33 & 0.016 \\
\hline C11 & 0.004 & C47 & 0.008 & C46 & 0.016 \\
\hline C43 & 0.004 & C33 & 0.005 & C43 & 0.009 \\
\hline C33 & 0.003 & C43 & 0.005 & C47 & 0.008 \\
\hline
\end{tabular}

\subsection{Step 4: Build a fuzzy goal programming model for powered roof support selection}

In the fuzzy GP model, all groups of sub-criteria are handled together; there are thus 24 decision criteria in total. The membership functions for each criterion are used as shown in Equation 12. Then the fuzzy goal programme developed earlier by the co-author [5] is used to compute the final priorities $[29,30]$. The notation and the model are given below.

Sets:

$i, j$ : Set of decision criteria, $1 . .24(C 11, C 12, \ldots, C 47)$.

Parameters:

$L_{i}$ : Lower bound for criteria $\boldsymbol{i}$ (given in Table 3).

$M_{\mathrm{i}}$ : Mid-value for criteria $\boldsymbol{i}$ (does not have to be mean of $L_{i}$ and $U_{i}$ ) (given in Table 3).

$U_{i}$ : Upper bound for criteria $\boldsymbol{i}$ (given in Table 3).

Decision Variables:

$\lambda$ : Decision variable related with fuzzy membership functions.

$W_{i}$ : Final priority (weight coefficient) of criteria $i, i: 1 . .24$.

$S_{i j}$ : Deviational variable of $W_{i}$ from $W_{j}$ considering the desired comparison value of criteria $i$ and $j$, i: $1 . .24$ and $j: 1 . .24$.

The model given in Equations 3 to 11 is written in Lingo 9.0 [31] and solved to optimum. In Equation 3, the objective function is to minimise the deviations from the fuzzy comparisons of decision criteria and to minimise $(-\lambda)$. Equation 4 states that the priorities of the decision criteria should be between the lower and upper bounds specified in Table 3. Equations 5 and 6 state that the values of the membership functions should be maximised. Equation 7 guarantees that the sum of all the decision criteria should be 1. From Equations 8 and 9, the deviations from pairwise comparisons are introduced. Finally, Equations 10 and 11 define the decision variables domains [5].

Model:

$$
\begin{gathered}
\text { Minimise } \sum_{\mathrm{i}=1 \mathrm{j}=1}^{\mathrm{n}} \sum_{\mathrm{ij}}^{\mathrm{S}} \mathrm{S}_{\mathrm{j}}-\lambda \\
\mathrm{L}_{\mathrm{i}} \leq \mathrm{W}_{\mathrm{i}} \leq \mathrm{U}_{\mathrm{i}} \quad \forall \mathrm{i}=1 . . \mathrm{n} \\
\lambda \leq \frac{\mathrm{W}_{\mathrm{i}}-L_{i}}{M_{i}-L_{i}} \quad \forall i=1 \ldots \ldots . n
\end{gathered}
$$




$$
\begin{gathered}
\lambda \leq \frac{\mathrm{U}_{\mathrm{i}}-W_{i}}{U_{i}-M_{i}} \quad \forall i=1 \ldots \ldots . n \\
\mathrm{~W}_{\mathrm{i}}+\mathrm{S}_{\mathrm{ij}}=M_{\mathrm{i}=1}^{\sum_{\mathrm{ij}}^{*} W_{\mathrm{j}} W_{i}=1} \quad \forall_{\mathrm{i}, \mathrm{j}}=1 \ldots . \mathrm{n}: M_{\mathrm{ij}} \geq 1 \\
\left(\frac{1}{M_{i j}}\right) * W_{i}=\mathrm{W}_{j}+S_{i j} \\
\forall_{\mathrm{i}, \mathrm{j}}=1 \ldots . . \mathrm{n}: \quad M_{\mathrm{ij}}<1 \\
0 \leq S_{i j} \leq 1 \quad \forall i, j=1 \ldots . . n \\
0 \leq \lambda \leq 1
\end{gathered}
$$

\subsection{Step 5: Find final priorities}

The output of the model in Step 4 gives the final priorities of the decision criteria, which are shown in Table 4. As seen in Table 4, C12, C11, C13, and C14 are found to be the most important sub-criteria according to the final priorities. Among the geological properties, seam thickness (C12) and working depth (C11) are found to be the most effective factors in roof support selection.

Table 4: Final priorities found by fuzzy GP model

\begin{tabular}{|c|c|c|c|}
\hline $\begin{array}{c}\text { Sub- } \\
\text { criteria }\end{array}$ & $\begin{array}{c}\text { Final } \\
\text { priority }\end{array}$ & $\begin{array}{c}\text { Sub- } \\
\text { criteria }\end{array}$ & $\begin{array}{c}\text { Final } \\
\text { priority }\end{array}$ \\
\hline C11 & 0.105 & C33 & 0.027 \\
\hline C12 & 0.139 & C34 & 0.031 \\
\hline C13 & 0.092 & C35 & 0.031 \\
\hline C14 & 0.091 & C36 & 0.024 \\
\hline C15 & 0.063 & C37 & 0.023 \\
\hline C16 & 0.063 & C41 & 0.008 \\
\hline C17 & 0.057 & C42 & 0.008 \\
\hline C21 & 0.053 & C43 & 0.006 \\
\hline C22 & 0.040 & C44 & 0.008 \\
\hline C23 & 0.041 & C45 & 0.016 \\
\hline C31 & 0.032 & C46 & 0.005 \\
\hline C32 & 0.034 & C47 & 0.003 \\
\hline
\end{tabular}

\subsection{Step 6: Rate the powered roof support alternatives}

The seven powered roof support alternatives are rated for all 24 decision criteria by the decisionmakers for the system. The scores (over 100) are given in Table 5.

Table 5: Rates of all powered roof support selection alternatives

\begin{tabular}{|c|c|c|c|c|c|c|c|}
\hline \multirow{2}{*}{$\begin{array}{c}\text { Sub- } \\
\text { criteria }\end{array}$} & \multicolumn{7}{|c|}{ Alternatives } \\
\cline { 2 - 8 } & A1 & A2 & A3 & A4 & A5 & A6 & A7 \\
\hline C11 & 70 & 80 & 70 & 60 & 80 & 50 & 75 \\
\hline C12 & 60 & 50 & 65 & 50 & 65 & 50 & 60 \\
\hline C13 & 75 & 80 & 70 & 60 & 80 & 40 & 80 \\
\hline C14 & 90 & 50 & 60 & 70 & 50 & 70 & 90 \\
\hline
\end{tabular}


Table 5 (cont.): Rates of all powered roof support selection alternatives

\begin{tabular}{|l|l|l|l|l|l|l|l|}
\hline \multirow{2}{*}{$\begin{array}{c}\text { Sub- } \\
\text { criteria }\end{array}$} & \multicolumn{7}{|c|}{ Alternatives } \\
\cline { 2 - 8 } & A1 & A2 & A3 & A4 & A5 & A6 & A7 \\
\hline C15 & 90 & 50 & 60 & 70 & 50 & 70 & 90 \\
\hline C16 & 70 & 80 & 70 & 50 & 80 & 50 & 75 \\
\hline C17 & 70 & 80 & 70 & 50 & 80 & 50 & 80 \\
\hline C21 & 70 & 90 & 75 & 45 & 90 & 45 & 85 \\
\hline C22 & 90 & 50 & 60 & 85 & 50 & 85 & 90 \\
\hline C23 & 80 & 90 & 60 & 70 & 90 & 70 & 90 \\
\hline C31 & 85 & 80 & 85 & 50 & 90 & 50 & 90 \\
\hline C32 & 85 & 80 & 70 & 60 & 75 & 80 & 90 \\
\hline C33 & 80 & 90 & 80 & 70 & 85 & 75 & 85 \\
\hline C34 & 80 & 70 & 80 & 70 & 70 & 70 & 90 \\
\hline C35 & 80 & 85 & 80 & 60 & 85 & 60 & 90 \\
\hline C36 & 80 & 70 & 80 & 60 & 70 & 60 & 90 \\
\hline C37 & 75 & 85 & 80 & 50 & 85 & 40 & 85 \\
\hline C41 & 80 & 75 & 70 & 75 & 75 & 65 & 75 \\
\hline C42 & 75 & 90 & 80 & 55 & 90 & 50 & 85 \\
\hline C43 & 90 & 90 & 90 & 90 & 90 & 90 & 90 \\
\hline C44 & 80 & 85 & 80 & 75 & 75 & 70 & 80 \\
\hline C45 & 90 & 70 & 80 & 80 & 70 & 80 & 90 \\
\hline C46 & 80 & 85 & 75 & 75 & 80 & 95 & 90 \\
\hline C47 & 65 & 65 & 70 & 90 & 70 & 90 & 90 \\
\hline
\end{tabular}

\subsection{Step 7: Find overall score of each powered roof support}

The final score (FinalScore) of each alternative is computed by weighted sum of individual scores, as given in Equation 12. The R matrix in Equation 12 is given in Table 5 and $\mathrm{W}$ is given in Table 4. Final scores can be seen in Table 6.

$$
\text { FinalScore }=R * W
$$

where

$$
\text { FinalScore }=\left[F S_{i}\right]_{1 \times n} T, R=\left\lfloor R_{i j}\right\rfloor_{k \times n}, W=\left[W_{i}\right]_{1 \times n} T
$$

Table 6: Final scores of powered roof support alternatives (over 100)

\begin{tabular}{|c|c|c|c|c|c|c|c|}
\hline Alternatives & A1 & A2 & A3 & A4 & A5 & A6 & A7 \\
\hline Final score & 76.27 & 70.91 & 69.52 & 60.47 & 72.91 & 58.11 & 81.07 \\
\hline
\end{tabular}

As seen from Table 6, the final scores of the alternative roof supports are all deterministic. The approach results in deterministic scores using fuzzy comparisons and fuzzy objectives. Providing deterministic results to the decision-maker is important, since in real life certain decisions are necessary for action. For example, the decision-maker would like to know which action to take and which alternative to select in the result. This study deals specifically with Omerler mine. Therefore the results were presented to them to show the most accurate roof support to select. It can be seen from Table 6 that the highest rank belongs to A7. However, A1, which is currently 
used at the colliery, is close to A7. Similarly, A2, A3, and A5 are close in performance. Finally, the worst-performing powered roof supports are A4 and $A 6$ because they have lower support resistances and lower operating heights than the others.

\section{CONCLUSION}

In longwall mining, selecting the most appropriate powered roof support involves a set of criteria that need to be considered. Here, different methods such as numerical analysis were employed, but not all criteria that are effective in support selection can be handled by numerical analysis. In this study, FAHP was used as a selection tool.

The criteria that are effective in support selection were investigated for four main topics and 24 sub-criteria. The human mind cannot directly and correctly compare seven alternatives over 24 decision criteria where the importance of each of these criteria varies. By applying the FAHP approach, these alternatives are compared to reach a final decision. In addition, fuzzy logic is used as a tool to decrease error, increase flexibility, and reach a more accurate decision. From the results, certain outputs were presented to the decision-makers.

Final scores were computed for each selection criterion, and $\backslash$ overall performance scores were identified for seven distinct support types. It was shown that, according to the performance scores, the most appropriate support is A7 with a score of 81.07 out of 100 . The performance score of the unit $A 1$, which is still used at the colliery, was shown to be 76.70. By using this technique, the decision-maker is provided with an alternative and powerful decision tool.

\section{REFERENCES}

[1] Deepak, D. 1986. Longwall face support design - a micro-computer model. Journal of Mines, Metals \& Fuels.

[2] Barczak, T.M. 1990. Selecting proper type of shield supports. Information Circular, Bureau of Mines.

[3] Wiklund, B., Kizil, M.S. \& Canbulat, I. 2011. Development of a cavity prediction model for longwall mining. Proceedings of the 11th Underground Coal Operators' Conference. Wollongong: University of Wollongong, pp. 48-59.

[4] Yavuz, M. 2015. The application of the analytic hierarchy process (AHP) and Yager's method in underground mining method selection problem. International Journal of Mining, Reclamation and Environment. 29(6), pp. 453-475.

[5] Ozfirat, P.M., Ozfirat, M.K., Malli, T. \& Kahraman, B. 2015. Integration of fuzzy analytic hierarchy process and multi-objective fuzzy goal programming for selection problems: An application on roadheader selection. Journal of Intelligent and Fuzzy Systems, 29, pp. 53-62.

[6] Yavuz, H. 2004. An estimation method for cover pressure re-establishment distance and pressure distribution in the goaf of longwall coal mines. International Journal of Rock Mechanics and Mining Sciences, 41(2), pp. 193-205.

[7] Goshtasbi, K., Oraee, K. \& Khakpour-Yeganeh, F. 2006. Shield support selection based on geometric characteristics of coal seam. Journal of Mining Science, 42(2), pp. 151-156.

[8] Oraee, K. \& Bakhtavar, E. 2010. Selection of tunnel support system by using multi criteria decisionmaking tools. The 29th International Conference on Ground Control in Mining. Morgantown, WV, 27-29th July.

[9] Singh, G.S.P. \& Singh, U.K. 2010. Prediction of caving behavior of strata and optimum rating of hydraulic powered support for longwall workings. International Journal of Rock Mechanics and Mining Sciences, 47(1), pp. 1-16.

[10] Kenny, P. 1969. The caving of the waste on longwall faces. International Journal of Rock Mechanics and Mining Sciences, 6(6), pp. 541-55.

[11] Salamon, M.D.G. 1990. Mechanism of caving in longwall mining. In: Hustrulid, J.G. (ed.), Proceedings of the 31st US rock mechanical symposium. Colorado.

[12] Ozfirat, M.K. 2012. A fuzzy method for selecting underground coal mining method considering mechanization criteria. Journal of Mining Science, 48(3), pp. 533-544.

[13] Medhurst, T.P. 2005. Practical considerations in longwall support behaviour and ground response. 6th Australasian Coal Operators' Conference, 2, pp. 49-57.

[14] Bingxiang, H., Hongtao, L., Changyou, L., Shijun, X. \& Weichao, X. 2011. Rational cutting height for large cutting height fully mechanized top-coal caving. Mining Science and Technology (China), 21, pp. 457-462.

[15] Simsir, F. 2015. Underground mining methods. Izmir: DEU Publications.

[16] Barczak, T.M. 2006. A retrospective assessment of longwall roof support with a focus on challenging accepted roof support concepts and design premises. 25th International Conference on Ground Control in Mining. Morgantown, pp. 232-244. 
[17] Mitchell, G.W. 2009. Longwall mining - Chapter 15. Australasian coal mining practice. Australasian Institute of Mining and Metallurgy.

[18] Barczak, T.M. 1989. Safety evaluations of longwall roof supports. Bureau of Mines.

[19] Once, G. \& Taskin, F. 2001. Study of optimum dimensioning of abutment pillars in longwall mining of GL(I)over-dot Tuncbilek Coal Mine. Rock mechanics: A challenge for society, pp. 843-848.

[20] Destanoglu, N., Taskin, F.B., Tastepe M. \& Ogretmen, S. 2000. Omerler mechanized longwall application. Ankara: Turkish Coal Administration (in Turkish).

[21] Yasitli, N.E. \& Unver, B. 2005. 3-D numerical modelling of stresses around a longwall panel with top coal caving. Journal of the South African Institute of Mining and Metallurgy, 105(5), pp. 287-300.

[22] Ozfirat, M.K. 2007. Investigations on determining and decreasing the coal loss at fully-mechanized production in Omerler underground coal mine. Institute of Natural and Applied Sciences, Izmir: Dokuz Eylul University (in Turkish).

[23] Simsir, F. \& Ozfirat, M.K. 2008. Determination of the most effective longwall equipment combination in longwall top coal caving (LTCC) method by simulation modelling. International Journal of Rock Mechanics and Mining Sciences, 45(6), pp. 1015-1023.

[24] Yang, M., Khan, F.I. \& Sadiq, R. 2011. Prioritization of environmental issues in offshore oil and gas operations: A hybrid approach using fuzzy inference system and fuzzy analytic hierarchy process. Process Safety and Environmental Protection, 89, pp. 22-34.

[25] Winston, W. 2003. Operations research: Applications and algorithms. $4^{\text {th }}$ edition, Duxbury Press.

[26] Ozfirat, P.M. 2014. A new risk analysis methodology integrating fuzzy prioritization method and failure modes and effects analysis. Journal of the Faculty of Engineering and Architecture of Gazi University, 29(4), pp. 755-768 (In Turkish).

[27] Ozfirat, M.K. 2015. Selection of tunneling machines in soft ground by fuzzy analytic hierarchy process. Acta Montanistica Slovaca, 20(2), pp. 98-109.

[28] Expert Choice Software, 2000. Expert Choice Inc., Pitssburg, USA.

[29] Karpak, B., Kumcu, E. \& Kasuganti, R.R. 2001. Purchasing materials in the supply chain: Managing a multi-objective task. European Journal of Purchasing and Supply Management, 7(3), pp. 209-216.

[30] Yıldız, A. \& Yayla, A.Y. 2015. Multi-criteria decision-making methods for supplier selection: A literature review. South African Journal of Industrial Engineering, 26(2), pp. 158-177.

[31] LINGO User's Guide. 2004. Chicago, USA: Lindo Systems Inc. 